\title{
Changes in glucose metabolism in premeiotic and meiotic ovaries of the hamster
}

\author{
A. B. Fajer \\ Department of Physiology, School of Medicine, University of Maryland, Baltimore, Maryland 21201, \\ U.S.A.
}

\begin{abstract}
Summary. The metabolism of glucose changed significantly at the time of the onset of meiosis in the hamster ovary. There was a large drop in the $\mathrm{CO}_{2}$ evolution from labelled glucose and it could be attributed to alterations in the metabolic patterns in the germ cells which represented $80-90 \%$ of the ovarian cell population at the time of the studies. The reduced glycolytic metabolism was well established in the oocyte at the diplotene stage of the first meiotic division.
\end{abstract}

\section{Introduction}

Mammalian germ cells show a different dependency on carbohydrate substrates during the various stages of their development. Although ejaculated spermatozoa metabolize more glucose to lactate than do testicular spermatozoa (Voglmayr, Scott, Setchell \& Waites, 1967), isolated round spermatids and pachytene spermatocytes do not survive in the presence of glucose but depend on a supply of lactate (Jutte, Grootegoed, Rommerts \& van der Molen, 1981; Mita \& Hall, 1982). In the female, after the initial observation that 2-cell mouse embryos could not develop in media supplying glucose as an energy source (Hammond, 1949), it was determined that this restricted glycolytic metabolism was already present in the zygote and maturing oocyte (Biggers, Whittingham \& Donahue, 1967), oocytes of various ages (Eppig, 1976) and the meiotic germ cells before follicle formation (Brinster \& Harstad, 1977). Some observations indicate that the preference for pyruvate over glucose is lower in the meiotic cells before follicle formation and in the fertilized ova (Brinster \& Harstad, 1977) and more accentuated in the follicular and ovulated oocytes (Eppig, 1976). This dependency on pyruvate and related compounds persists until the 8-cell stage of embryo development (Whitten, 1956; Brinster, 1965a, b).

It is not clear, at least in the female, whether the restricted glycolytic pattern plays some role in early embryogenesis or it is characteristic of gametogenesis and simply carried over after fertilization. The present study examined when this metabolic pattern is established and whether it is present at all stages of germ cell development or is related to other events that occur during gametogenesis.

\section{Materials and Methods}

Animals. Golden hamsters (Mesocricetus auratus), 100-120 $\mathrm{g}$ body weight, were used. Groups of 610 animals were mated on the evening of pro-oestrus. Half of the animals in each group became pregnant. The schedule was such that, on the day of the experiment, there were pregnant animals on the 14th day post coitum, and newborn females 3 or 5 days of age. The difference of age between 
the fetuses and newborn was 5 and 7 days. Pregnancy in this hamster colony lasts $16-16 \frac{1}{2}$ days. Because the age difference was large and the age-related ovarian structures were strikingly different, no closer age definition was sought.

In each experiment, fetal ovaries were obtained from 2 or 3 litters and randomly distributed. A total of 53 pregnant animals was used; 5 newborn females were studied at 3 days and 27 at 5 days of age.

Stages of meiosis and cell distribution. When haematoxylin-eosin stained sections were analysed, the germ cells covered $90 \pm 1.5 \%$ of the area of the fetal ovary $(n=5)$ and $81 \pm 4.0 \%$ in the 5-dayold hamster ovary $(n=5)$. Meiosis in the hamster can be detected clearly on the 1st day after birth. On Days 3 and 5 of age about $50 \%$ and $85 \%$ respectively of the germ cells are in meiosis (Fajer, Schneider, McCall, Ances \& Polakis, 1979).

Protein determination. Ovarian protein concentration was determined by the Coomassie Blue dye method (Bio Rad, California) using a purified bovine serum albumin (Sigma, St Louis) as the standard.

Determination of ${ }^{14} \mathrm{CO}_{2}$ during tissue incubation with $\left[U \cdot{ }^{14} \mathrm{C}\right]$ glucose. Carbon dioxide production from labelled glucose was determined using a glucose-free medium made up from a MEM kit (Gibco, New York). Five $\mu \mathrm{Ci}\left[\mathrm{U}-{ }^{14} \mathrm{C}\right]$ glucose (sp.act. $225 \mathrm{mCi} / \mathrm{mmol}$ : Amersham, Chicago) were added to $1 \mathrm{ml}$ medium in a $20-\mathrm{ml}$ sterile glass vial closed with a rubber stopper. Each vial received 2 ovaries and 3-5 vials were used for each determination. Results are expressed in d.p.m./100 $\mu \mathrm{g}$ ovarian protein.

The radioactivity was determined in a proportional counter (Bactec: Johnston Laboratories, Baltimore) after each vial had been flushed automatically with $5 \% \mathrm{CO}_{2}$ in air, every $30 \mathrm{~min}$. The incubations at $37^{\circ} \mathrm{C}$ under $5 \% \mathrm{CO}_{2}$ in air lasted for $150 \mathrm{~min}$. The determinations were done after the first $60 \mathrm{~min}$ when the $\mathrm{CO}_{2}$ production (counts) reached a plateau and stayed stable for the next three readings. No trapped radioactive $\mathrm{CO}_{2}$ was found when $2 \mathrm{ml}$ of a $10 \%$ solution of perchloric acid were added to each vial after the incubation. The number of ovaries and the amount of labelled glucose were adjusted to obtain a linear relationship between mass and $\mathrm{CO}_{2}$ production and to use the most stable region of the detector. The experiments were always done simultaneously in all age groups to avoid the effects of variations between batches of radioactive compounds or their oxidation. Vials without tissues were used as controls.

\section{Results}

The results shown in Table 1 clearly indicate that in the fetal ovaries the glucose oxidation was 4.711 times higher than in the meiotic ovaries of 5-day-old hamsters. In these meiotic ovaries, of the $85 \%$ of the germ cells in meiosis, $40 \%$ had reached the pachytene stage.

Table 1. Carbon dioxide production (d.p.m. $\times 10^{-3} / 100 \mu$ g ovarian protein) by premeiotic and meiotic hamster ovaries in vitro

\begin{tabular}{ccccc}
\hline Exp. & $\begin{array}{c}\text { Premeiotic } \\
\text { ovary }\end{array}$ & $\begin{array}{c}\text { Meiotic } \\
\text { ovary }\end{array}$ & $\begin{array}{c}\text { Ratio of } \\
\text { premeiotic/meiotic } \\
\text { ovary value }\end{array}$ & $\begin{array}{c}\% \\
\text { decrease } \\
\text { meiotic/premeiotic }\end{array}$ \\
\hline 1 & $130 \pm 6$ & $15 \pm 0 \cdot 7$ & $8 \cdot 6$ & 88 \\
2 & $110 \pm 7$ & $13 \pm 1 \cdot 0$ & $8 \cdot 4$ & 88 \\
3 & $122 \pm 7$ & $11 \pm 1 \cdot 0$ & $11 \cdot 0$ & 90 \\
4 & $124 \pm 7$ & $26 \pm 4 \cdot 0$ & $4 \cdot 7$ & 83 \\
5 & $133 \pm 10$ & $22 \pm 1 \cdot 6$ & 6.0 & 87.7 \\
Mean & $123 \cdot 7 \pm 5 \cdot 1$ & $15 \cdot 2 \pm 2.4$ & 8.1 & \\
\hline
\end{tabular}


In another experiment in which the fetal ovaries were compared to 3- and 5-day-old ovaries, the 3-day-old ovaries, which show $45 \%$ of the germ cells at the leptotene stage of meiosis, had a glucose oxidation value that was $37 \%$ of that of the fetal ovaries. The 5-day-old ovaries showed $\mathrm{CO}_{2}$ production that was $25 \%$ of that of the fetal ovaries.

Between the 14th day of gestation and the 5 th day after birth the mean \pm s.e.m. ovarian protein content per ovary increased from $9.9 \pm 0.4(n=10)$ to $19.6 \pm 1 \cdot 2(n=8) \mu \mathrm{g}$ protein/ovary.

\section{Discussion}

The present observations strongly suggest that the changes in glycolytic metabolism observed in premeiotic and meiotic ovaries can be attributed to the germ cells at the onset of meiosis. From the 14 th day of gestation to the 5 th day after birth, the ovary grows and the protein content doubles. At the same time the somatic cell population multiplies at a faster rate than does that of the germ cells. The somatic cell participation goes from 10 to $19 \%$, while the germ cell fraction falls from 90 to $81 \%$. These simple calculations exclude the somatic cells as the source of a reduced glucose oxidation. Therefore, if the $\mathrm{CO}_{2}$ evolution by the germ cells did not change, the $9 \%$ shift in their distribution cannot explain the average drop of $87 \%$ in glucose oxidation (range $79-90 \%$ ).

During this period of ovarian development there are no significant structural changes: follicles have not yet formed and the adult circulatory pattern has not been established.

The results have to be seen in the context of the pattern of glycolytic inhibition seen in the oocyte at the diplotene stage (Biggers et al., 1967). This inhibition is possibly due to a block at the level of phosphofructokinase (Barbehenn, Wales \& Lowry, 1974) and hexokinase (Brinster, 1968) because it occurs in preimplantation embryos.

The permeability of the germ cells to glucose, lactate and pyruvate has not been studied in many species. Experiments have shown that early mouse embryos accumulate glucose, are freely permeable to lactate and have a very small intracellular pool of pyruvate (Wales, 1975). The problem of oocyte permeability is further complicated by the studies of cell co-operation. The integrity of the junctional contact between oocyte and granulosa cells is required for the normal growth of the oocyte (Eppig, 1979) as well as for the uptake of 2-deoxyglucose by the oocyte (Brower \& Schultz, 1982). It has not been defined when this metabolic dependency of the germ cells is established. Alternative metabolic pathways to glucose oxidation have not been studied in the hamster oocyte or early embryo. However, in the rabbit the pentose shunt is very active (Fridhandler, 1961), while the Krebs' cycle predominates in the mouse (Brinster, 1969). Metabolically, there is a similarity between the gametes of the 2 sexes. The oocytes use pyruvate that the granulosa cells are capable of producing (Donahue \& Stern, 1968); in the male spermatocytes and spermatids require lactate that is produced by the Sertoli cells (Jutte $e t$ al., 1981).

If the changes in glycolytic metabolism are associated with the onset of meiosis, it is not clear to which other events occurring at the same time they can be associated. Some of the enzymes involved in glucose metabolism are X-chromosome coded (De La Chapelle \& Miller, 1979) but this has not been shown for the two enzymes that have reduced activity in the early embryo.

The reactivation of the second $\mathrm{X}$-chromosome in the female occurs at a time close to the beginning of meiosis (Migeon \& Jejalian, 1977; Gartler, Rivest \& Cole, 1980; Monk \& McLaren, 1981), but in spite of the changes detected in the expression of some enzymes coded in the Xchromosome (Monk \& McLaren, 1981), the reactivation of the second chromosome does not seem to be involved with the onset of meiosis (Jagiello, Downey \& Ducayen, 1982). These observations, taken together, would indicate that the cycles of the X-chromosome do not influence the glucose metabolic patterns. 
The importance of the changes in glucose metabolism in relation to the change from mitosis to meiosis and the effects of the various meiosis-influencing mesonephric factors (Byskov, 1978; Fajer, 1981) on the metabolism of premeiotic ovaries remain to be elucidated.

I thank Mrs Jane Garber for technical assistance. This work was supported in part by a grant of The National Institutes of Health (NICHD No. 13087), Bethesda, Maryland.

\section{References}

Barbehenn, E.K., Wales, R.G. \& Lowry, O.H. (1974) The explanation for the blockade of glycolysis in early mouse embryos. Proc. natn. Acad. Sci. U.S.A. 71, $1056-1060$.

Biggers, J.D., Whittingham, D.G. \& Donahue, R.P. (1967) The pattern of energy metabolism in the mouse oocyte and zygote. Proc. natn. Acad. Sci. U.S.A. 58, 560-567.

Brinster, R.L. (1965a) Studies on the development of mouse embryo in vitro. II. The effect of energy source. J. exp. Zool. 158, 59-68.

Brinster, R.L. (1965b) Studies on the development of mouse embryos in vitro. IV. Interaction of energy sources. J. Reprod. Fert. 10, 227-240.

Brinster, R.L. (1968) Hexokinase activity in the preimplantation mouse embryo. Enzymologia 34, 304-308.

Brinster, R.L. (1969) In-vitro cultivation of mammalian ova. Adv. Biosci. 4, 200-233.

Brinster, R.L. \& Harstad, H. (1977) Energy metabolism in primordial germ cell of the mouse. Expl Cell Res. $109,111-117$

Brower, P.T. \& Schultz, R.M. (1982) Intercellular communication between granulosa cells and mouse oocytes: existence and possible nutritional role during oocyte growth. Devl Biol. 90, 144-153.

Byskov, A.G. (1978) Regulation of initiation of meiosis in fetal gonads. J. Androl., Suppl. 2, 29-38.

De La Chapelle, A. \& Miller, O.J. (1979) Report of the committee on the genetic constitution of chromosomes 10, 11, 12, X and Y. Cytogenet. Cell Genet. 25, 47-58.

Donahue, R.P. \& Stern, S. (1968) Follicular cell support of oocyte maturation : production of pyruvate in vitro. J. Reprod. Fert. 17, 395-398.

Eppig, J.J. (1976) Analysis of mouse oogenesis in vitro. Oocyte isolation and utilization of exogenous energy sources by growing oocytes. J. exp. Zool. 198, 375382.

Eppig, J.J. (1979) A comparison between oocyte growth in co-culture with granulosa cells and oocytes with granulosa cell oocytes junctional contact maintained in vitro. J. exp. Zool. 209, 345-353.

Fajer, A.B. (1981) The ovarian and extraovarian control of meiosis: the role of haploidins. In Bioregulators of Reproduction, pp. 97-106. Eds G. Jagiello \& H. J. Vogel. Academic Press, New York.

Fajer, A.B., Schneider, J., McCall, D., Ances, I.G. \& Polakis, S.E. (1979) The induction of meiosis by ovaries of newborn hamsters and its relation to the action of the extraovarian structures in the mesovarium. Annls Biol. anim. Biochim. Biophys. 19, 12731278.

Fridhandler, L. (1961) Pathways of glucose metabolism in fertilized rabbit ova at various pre-implantation stages. Expl Cell Res. 22, 303-316.

Gartler, S.M., Rivest, M. \& Cole, R.E. (1980) Cytological evidence for an inactive $\mathrm{X}$-chromosome in murine oogonia. Cytogenet. Cell Genet. 28, 203-207.

Hammond, J. (1949) Recovery and culture of tubal mouse ova. Nature, Lond. 163, 28-29.

Jagiello, G., Downey, S. \& Ducayen, M. (1982) Xchromosome heteromorphism and appearance of meiosis in the rat fetal ovary. Devl Biol. 90, 223-225.

Jutte, N.H.P.M., Grootegoed, J.A., Rommerts, F.F.G. \& van der Molen, H.J. (1981) Exogenous lactate is essential for metabolic activities in isolated rat spermatocytes and spermatids. J. Reprod. Fert. 62, 339-405.

Migeon, B.R. \& Jejalian, K. (1977) Evidence for two active X-chromosomes in germ cells of female before meiotic entry. Nature, Lond. 229, 242-243.

Mita, M. \& Hall, P.F. (1982) Metabolism of round spermatids from rats: lactate as the preferred substrate. Biol. Reprod. 26, 445-455.

Monk, M. \& McLaren, A. (1981) X-chromosome activity in foetal germ cells of the mouse. J. Embryol. exp. Morph. 63, 75-84.

Voglmayr, J.K., Scott, T.W., Setchell, B.P. \& Waites, G.M.H. (1967) Metabolism of testicular spermatozoa and characteristics of testicular fluid collected from conscious rams. J. Reprod. Fert. 14, 87-99.

Wales, R.G. (1975) Maturation of the mammalian embryo: biochemical aspects. Biol. Reprod. 12, 66 81.

Whitten, W.K. (1956) Culture of tubal ova. Nature, Lond. 176, 96-97.

Received 22 December 1982 